\title{
Fire Mitigation Boardgame for Elementary Student at Sintang Region
}

\author{
Nelly Wedyawati ${ }^{1}$, Antonius Edy Setyawan ${ }^{2}$ \\ \{email: Nellywedyawati@ymail.com ${ }^{1}$, email:edysetyawan.200286@gmail.com² ${ }^{2}$,
}

STKIP Persada Khatulistiwa Sintang, Indonesia

\begin{abstract}
Sintang Region is an area of level II in the Kalimantan Barat (West Borneo). The wide area of the land is $21.635 \mathrm{Km}^{2}$, most the areas are forest and soil. Sintang Region Fire Department was stated that fire disasters, including soil, forest, and settlement fire always became a similar problem every year, especially in the dry season. On the year 2015, a fire was a huge disaster that happened in Sintang Region. Fire Department already tried hard to prevent that fire disaster. Socialization and Education already did by the Fire Department but that was not effective and efficient. The elementary school student is the part of the social community that needs socialization to prevent fire disasters. The boardgame is important to prepare the student to prevent the fire disaster. The product (draft) of the fire mitigation Boardgame will call "GaMikar". The developing method used qualitative and quantitative approaches. The qualitative method used to get the material of fire mitigation and searching the fit template design. The quantitative method used at the processing to produce valid media based on the validator. The research result was draft "GaMikar" that already valid with a percentage of $95,53 \%$ by the validator of learning media and $88,8 \%$ by the validator of fire mitigation. Based on that, the researchers conclude that "GaMikar" was fit and proper to continuing and testing for the sample.
\end{abstract}

Keywords: mitigation, boardgame, fire, GaMikar, Sintang, Elementary.

\section{Introduction}

Forest and land fires (Karhutla) on Kalimantan Island occur almost every year with a high intensity along with the coming of the dry season and have caused various negative impacts at all levels, both national and regional local. The area of degraded land in the Kalimantan Island region in 2010 reached around $34.09 \%$ of the total area of degraded land in Indonesia. Based on data from BNPB's Indonesian Disaster Data and Information (DIBI), the most dominant natural disasters in the Kalimantan region are forest and land fires, floods and drought [1]. People who drive are forced to wear masks to avoid the danger of smoke, eyes, and shortness of breath [2]. Schools in Kalimantan had to be closed and resulted in disruption of the learning process [2]. The fire that caused the victim [3]. Karhutla certainly has a big influence on the economy of West Kalimantan. In terms of logistics distribution, concentrated smoke certainly obstructs the visibility of drivers who transport logistics. Haze causes visibility to decrease. So some effort transportation decided not to operate. Because the impact on inflation has a huge impact on the allowance for commodity prices set by the government [4].

Some evidence showed that people need their science education. Based on the opening mandatory UUD of the 1945 Constitution that homeland is responsible to protect the entire 
Indonesian nation and the entire country of Indonesia. The Government should protect life and livelihood, including the protection of the disaster to make the "Nation Tough Facing Disasters". A disaster-resilient nation is a nation that can overcome disasters through adaptation in rebuilding lives in a better way. Emergency preparedness and response is the last solution to reduce risk when prevention and mitigation have not worked well. Academics need to become national partners in disaster management. Academics can play a role by maximizing disaster education in learning.

One effort that can be done to improve students' understanding of disaster mitigation is by providing learning media. Learning media have used to clarify the presentation of the message so that it is not too verbal and able to overcome the limitations of space, time, senses, such as objects that are too large can be replaced with pictures or models, and also concepts that are too broad can be visualized in the form of film or picture. Elementary school-age children are at the stage of concrete operations that can logically reason about concrete events and classify objects in different forms by applying a concrete example. Thus boardgame media is an appropriate and effective media for developing fire disaster response attitudes for children by displaying concrete fire mitigation concepts. When playing the game, children can do a variety of interactions and decision making by considering various conditions.

Children can also change their decisions based on certain scenarios which certainly involve logic. According to research playing games, children experience experiences that far exceed what they get in the class [5]. So the purpose of the research conducted by the author is "designing a fire mitigation education board game for elementary school children that are feasible, valid and effectively used". The game has the advantage of education which has a great positive potential as a medium of education in addition to the entertainment provided and ad a likelihood of success were high when a game is designed to teach a skill that material or specific [6]. Games can easily attract children to give full attention and concentration to what is presented.

Games can engage children interactively and offer adventures, challenges, and problems that must be resolved without real consequences. This can provide positive stimulation to children so they can be more involved and interested in the ongoing education process. The design of the fire mitigation board game used the learning and play approach. Learning and play methods will help children improve brain intelligence and gain knowledge of fire mitigation. This approach will indirectly give children a learning experience [7]. With learning media in the form of games, children can improve motoric performance so that they can think and act properly in time [8].

In general, the age of students in elementary school ranges from 6/7 - 13/14 years. This age enters the end of childhood where children have learned to socialize in a wider environment, namely school meaning that children begin to learn socializing [9]. Kids hit the 1 world through four stages of cognitive development is the sensory stage motor, the preoperative stage, the stage of concrete operations. The sensorimotor stage starts from birth-2 years, the pre-surgery stage lasts \pm age 2-7 years, and at the stage of concrete operations \pm age 7-11 years. So, elementary school-age children no longer think about what they do or don't do, but rather tend to think about what they can do compared to what other children can do. In other words, in this period children increasingly involve social and psychological characteristics including social comparison. When entering elementary school age, children begin to express objective ideas. Elementary school children begin to shift their attention towards collaboration with game groups; children are expected to gain an important knowledge base for self-success in adult life in the form of mastering various skills [10]. 
Children aged 7-11 years have sufficient intellectual ability to become the basis given a variety of skills that can develop the mindset of children, including knowledge about fire mitigation. One of them is besides the basic concepts of science and other knowledge [11], from a previous study on the application of learning models that have been integrated with disaster mitigation, which can improve disaster response attitudes [12]. The implementation of the disaster mitigation learning model is also effective for improving the learning outcomes of elementary school children [13]. The disaster mitigation learning model is also responded positively by elementary school children who become research samples [14].

Disaster risk reduction education is a consistent and planned effort in the learning process to empower children to build a culture of safety and resilience to disasters. Children are even able to develop motivation, skills, and knowledge to be able to act and take part in efforts to reduce disaster risk. The implementation of disaster risk reduction is carried out as an act of disaster management and requires schools to carry out these teaching activities. Implementation efforts are carried out through three steps, namely: (1) prevention, prevention is a series of activities carried out to eliminate and or reduce the threat of disaster, (2) mitigation, mitigation is a series of efforts to reduce disaster risk, both carrying out physical development and awareness-raising and increasing the ability to face the threat of disaster, and (3) preparedness, preparedness is a series of actions taken to anticipate disasters through organizing as well as through appropriate and efficient steps.

The material mitigation action learning process is divided into four stages (1) introduction, in this stage the child taught to do an introduction to the state of the environment and do an introduction to a variety of sources fire, (2) prevention, this stage when the kids start learning activities focused on the prevention stage. In addition to information, children are also required to understand how to take precautions to prevent fires, (3) handling, at the handling stage at the handling stage is the stage where physical contact with objects that have the potential to cause a fire begins, how to deal with it and control the fire so that it does not cause casualties, and (4) recovery, at this stage are taught how to do first aid and medical action taken so that fire victims can be helped immediately.

\section{Method}

The study used a quantitative approach and the qualitative approach. The qualitative method used as a reference to get the concept boardgame mitigation of fires and find the design criteria that proper to elementary school children. Quantitative methods used in the research process were the research and development model of Borg and Gall. The stages of research can be seen in Figure 1 below.

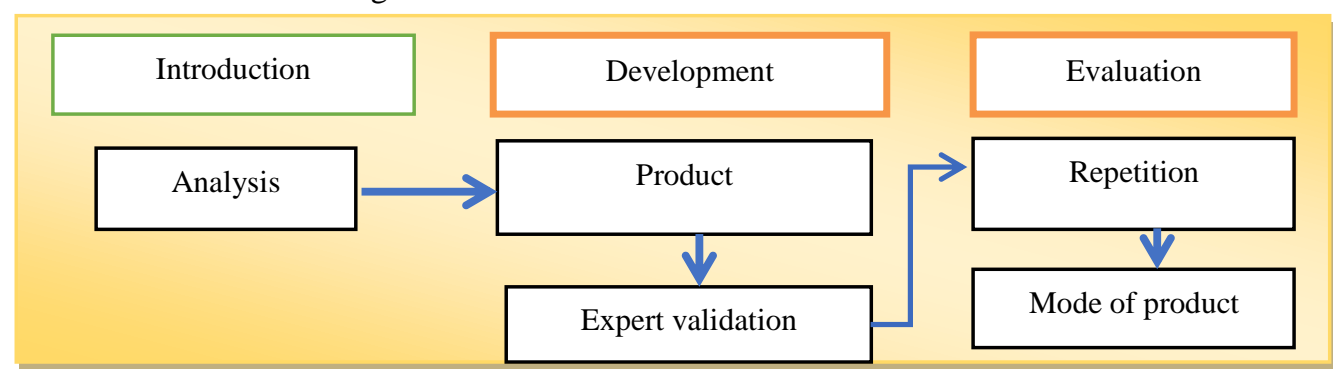

Fig. 1. Designing stages Boardgame as educational media fire mitigation 
In the analysis phase using quantitative data that was the questionnaire of interests and characteristics of children based on grade level, qualitative data (depth interview) of the fire mitigation study to the Sintang region fire brigade officers and academics related to the learning of elementary school children. Data qualitative observations to 4,5,6 grade elementary school children in Sintang. The results of observations aim to explore data, look for children's favorite and then determine the initial concepts for the criteria for designing boardgame. The data of fires incident over the last 3 years in the area of service Fire Department Sintang, journal or book that related to the designing board games and mitigation of fires, documentation, and survey research data collection.

Product development that was developed based on the following criteria: (1) visual aspects include the use of colors, layouts, drawing styles, and typography of writing, (2) the audio aspect with playgroups, applying the concept of game based on learning and playing system, language selection and giving reward or punishment to players and (3) effective aspect: the concept of "safety first " attitude that teach children how to play with fire without having to fear when the child knows all the information and always prioritize safety. How does the child see fires in a way that is fun to deal with when the child knows all the information needed to prevent and deal with fires so that the child can face calmly and not cause a panic situation.

The validation of products was the stage of validation by the expert of instructional media and the experts of fire mitigation. The product improvement: based on the findings of the trial product shortage board game will be revised following the stages of product enhancements observation, interviews, results of expert validation and expert media fire mitigation. The final product, at this stage the fire mitigation board game media has been obtained which is ready to be generalized and used. Indicators of research achievements are based on the validator's assessment of the product were $\geq 80 \%$.

\section{Results and discussion}

In this preliminary stage, the authors conducted a needs analysis by conducting interviews with depth interviews with the head of the Sintang district fire department. Information obtained from the interview included that the Sintang district government, in this case, the civil service police unit, was always working to prevent and minimize fire disasters, both forest and land fires, and residential residents' fires. The fire department always appeals to the public not to burn trash and throw away cigarette butts carelessly, especially during the dry season. It also continues to establish cooperation with the community in efforts to prevent fire disasters through socialization and assistance to the community in the form of training in using simple fire extinguishers free of charge. 


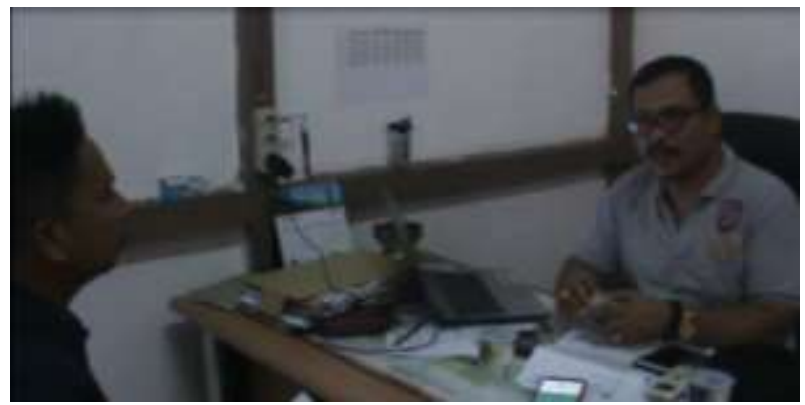

Fig. 2. Interview with the Head of the Sintang District Fire Department

The fire department's preparedness can be seen from the fire brigade's car that is always in a ready condition and also the firefighters who are always on guard 24 hours if they get reports from the community at any time about the fire disaster. Another effort that has been made from the fire department is to disseminate telephone numbers that can be contacted at any time 24 hours in the event of a fire disaster. Information cards distributed to the public can be seen in Figure 2.

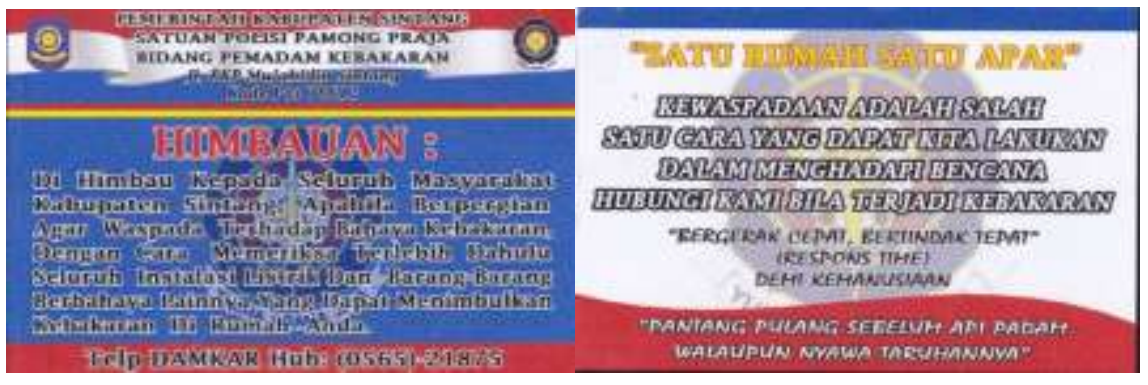

Fig. 2 . Sintang District fire department information card

From some of the above efforts that have been made by the Sintang district fire department, there are still many obstacles. Public awareness of fire preparedness is still lacking. This can be seen from the fact that there are still very few houses that do not have fire extinguishers, especially in densely populated areas. Also, there are often conditions of delay in residents in reporting fire incidents. When there was a fire, many people flocked to the scene just to see. This is a concern as well as an obstacle when firefighters who want to go to the scene. Geographical conditions that are wide enough for the Sintang district are also a big challenge for the fire department if they receive a report of a fire disaster in an area that is difficult to reach by road vehicles. Other efforts undertaken to prevent the occurrence of fire disasters are by conducting socialization and training.

In the last three years, the fire department has carried out socialization and training activities to the community both among the general public and among students. The activity is carried out free of charge because this is part of a commitment of the fire department in fire mitigation efforts in the Sintang district. However, because the district of Sintang very spacious the activity has not run optimally, especially for socialization and training of fire mitigation among students. The fire mitigation socialization and training activities that have been carried out so far have only been conducted at several high and middle-level schools and 
several universities. For information dissemination activities and fire mitigation training for elementary school students has never been done. Therefore the Sintang district government, in this case, is the fire department is very welcomed with the research conducted by the author to help socialize and fire mitigation training, especially for elementary school students who so far have never been touched by assistance and training on fire mitigation.

Gamikar is an extension of the Fire Mitigation Game. Based on preliminary studies that have been carried out, one form of socialization to prevent the occurrence of fire disasters for elementary school students is in the form of games. Games containing educational elements are developed in such a way that by playing Gamikar indirectly the elementary school students can understand and understand material about fire disaster mitigation. So this game is expected to be able to create a generation of disaster preparedness early on. As for some of the items in a game developed by the authors, there was as follows:

\section{Boardgame}

Boardgame has developed using the region of Sintang as the background of the region. The purpose of used Sintang as a background town because is to be more conceptual and familiar to the student in the town of Sintang. The game is square with a side length of $55 \mathrm{~cm}$. This site is considered ideal for children after elementary school because it is neither too small nor too big. The gameboard contains the player's route number. In some route numbers, there are fire symbols, water symbols, and free route symbols. The board can be seen in Figure 3 below. The material used to make this board game is to use albatross paper. The selection of this type of paper was chosen because it has a soft, smooth, and thin but strong texture, besides it is not easily torn when it folded.
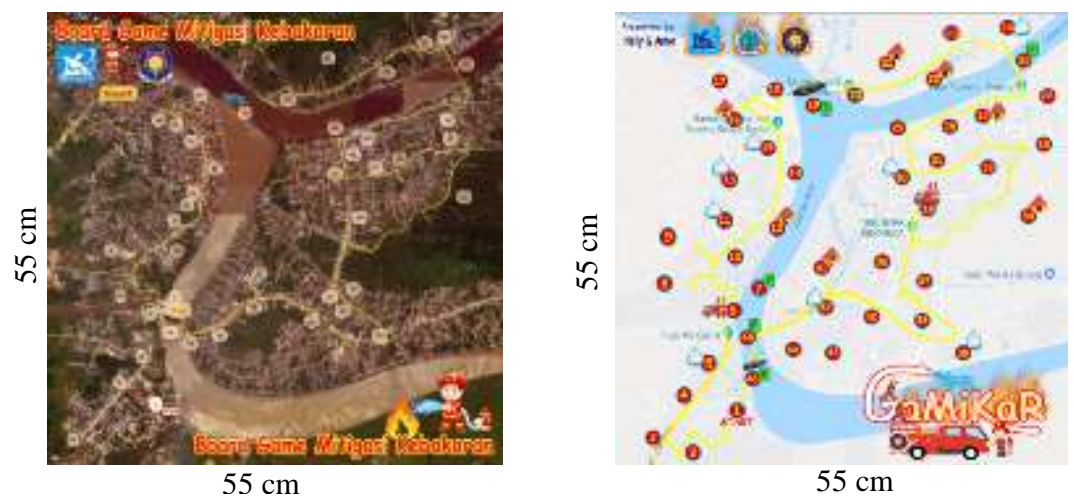

Fig. 3. Developed game board (left), and after validation (right)

\section{Fire pin}

A fire disaster starts with a fire. This game started with using the firing pin as a symbol of fire. The firing pin was well designed and attractive by paying attention to the color and brightness display. The use of color taken into account the visual aspect so that it attracted interest, and the symbol of fire can be stored in a student's long memory so that awareness of fire increases. The firing pin designed to be rectangular with a height of $4 \mathrm{~cm}$ and a side length of $2.8 \mathrm{~cm}$. Fire pin printed using art paper $100 \mathrm{gr}$. The player was entitled to get a firing pin if he has successfully extinguished the fire following the type of fire and the extinguisher card owned. The more fire pins a player gets, the player will be the winner. 

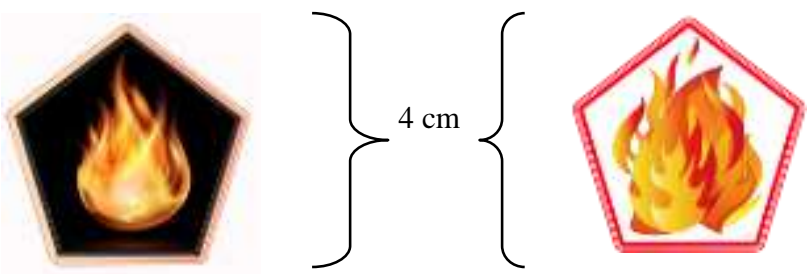

Fig. 4. Fire pin developed (left), and fire pin after validation

\section{Water pin}

Water is a very important element in a fire disaster, but not all fires can be extinguished by water. There are some kinds of fire caused by the short electric circuit (short-circuiting), rubbing alcohol (spirits), gasoline, and chemicals that will be enlarged if doused with water. This concept inserted in the question card as student knowledge. Water was used to put out fires in case of fire. So in this game, there was also a water pin. The water pin designed in the shape of a pentagon with a height of $4 \mathrm{~cm}$; side length is $2.8 \mathrm{~cm}$ and printed using $100 \mathrm{gr}$ art papers. Water pin used a symbol of water with an attractive color according to children's tastes. Players who stop at the route number that contains the water symbol, then the player was entitled to get a water pin. The route numbers contained in the water pin symbol are numbers: $5,11,13,15,24,30,39$, and 42 .

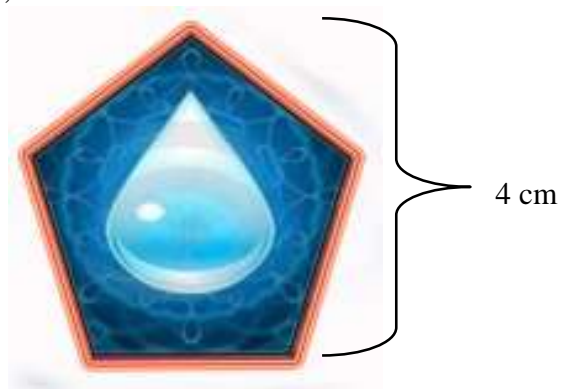

Fig. 5. Water pin

\section{IDR coin}

Rupiah (Indonesian currency) coin pin is a symbol of money. This Rp coin pin was printed in a circle with a diameter of $4 \mathrm{~cm}$ and printed using $100 \mathrm{gr}$ art paper type. Players will get a coin pin if they successfully answer the question contained on the question card. One coin can be used to exchange 2 water pins if the player runs out of water pins. The existence of a coin pin was intended as a reward to increase student motivation in answering several questions. The more questions that can be answered, the more players will get pin coins.

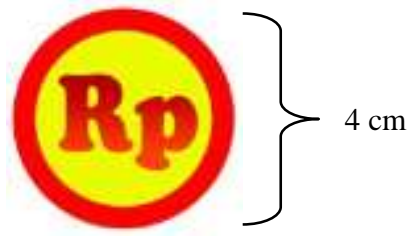

Fig. 6. Pin Koin 


\section{Question card}

Amount of 27 statements cards containing material on fire mitigation. Question cards are printed using $100 \mathrm{gr}$ art paper with a length of $8.5 \mathrm{~cm} \times 5.5 \mathrm{~cm}$ width. The 27 questions are the development of the fire mitigation grid. The typeface used in the question card was using the Comic Sans MS typeface because this typeface is more familiar among children. If the player stops on a route number that does not have water or a fire symbol or a free route, then the player must take one question card and answer it. The material mitigation of fires that were presented in the question cards, among others, are as follows [16] theory of occurrence of fire, fire prevention, how to save important documents, the type of the threat of fire, the stage of development of the fire, the fire escape in the event of fire, the nearest and safe location to rescue themselves, the steps to help with burn, the tools and materials for first aid in minor burns, and the classification of burns.
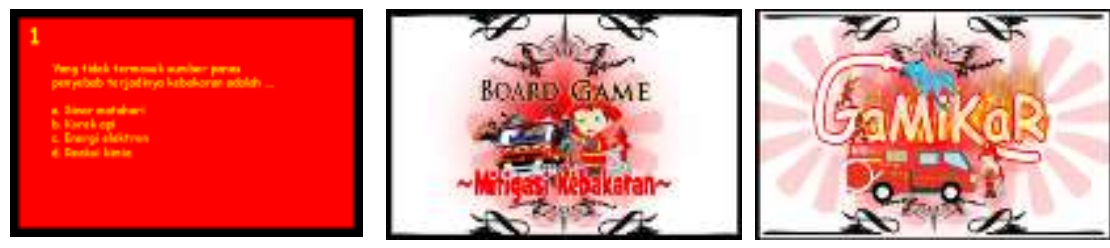

Fig. 7. Side view of Question Cards (left); cover question cards before validation (middle); question card cover after validation (right)

6. Fire extinguisher card

The card fire brigade in the game consists of three cards like in figure 8 with long card size $5 \mathrm{~cm} \times 4 \mathrm{~cm}$ wide. The three of the card type fire extinguisher consists of drawing fire extinguishers, hydrants, and call center Fire Department. In addition to introducing fire fighting equipment to an elementary student, the purpose of making this card was to make it even more ingrained in their minds that not all types of fires can be extinguished with water, depending on the main cause of the fire. It also instills the early generation of disaster preparedness by introducing an emergency telephone number that can be contacted in the event of a fire disaster. Because not all people know the telephone numbers of the Sintang district fire department or the national call center for fire emergencies.

As an initial capital when the game starts, each player was entitled to get 2 pieces of fire extinguisher cards each. Each player will get a card Fire Department again when the player stops at these numbers with symbols Fire Department post is number 6 and 35. If the player stops on route number contained fire symbol (numbers 12, 16, 21, 22, 27, 34, 41) then the player must throw water pin held along with the card fire extinguisher following the type of fire that placed on the route number. As a reward for players, they will get one fire pin. Conversely, if at the time the player was on the route number that has the fire symbol and runs out of water pins and or fire card, then the player was declared knocked out and lose. 

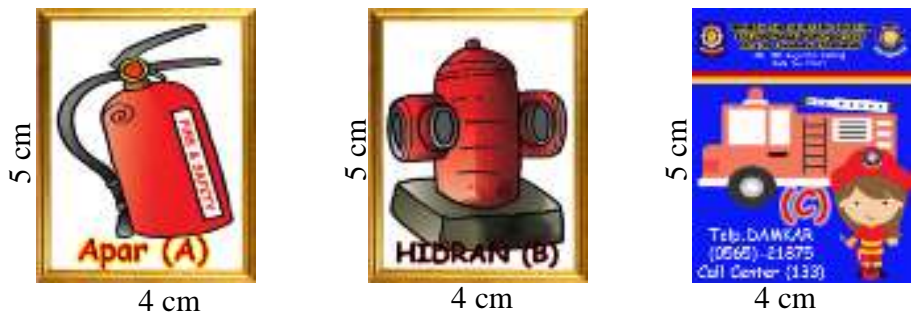

Fig.8. Fire Card

\section{Player piece}

Pawn is a symbol of the player in this game. The pieces consist of 4 characters, referred to as 4 fire patriots. The four fire patriots have their respective names namely Anton, Tom, Nelo, Miti. The material of this piece was made from mica with a $4 \mathrm{~cm}$ height with 2 -dimensional models.

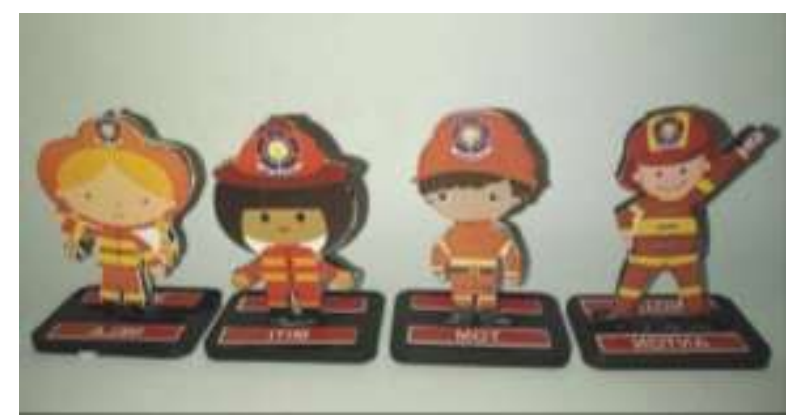

Fig.9. Fire Pawn Piece

8. Rule of the game

Every game must have rules. In this fire mitigation game, the author has designed rules that must be known and obeyed by every player. The rules in this fire mitigation game are as follows: (1) players number 2 - 4 people, (2) as an initial provision, players are entitled to get 2 Air Pins, 2 pieces of APAR card, 2 pieces of Hydrant card, and 2 Emergency Call Cards 113 , (3) players roll the dice in turns, the most numbers playing in the past. The game starts from the START sign, (4) after that the player is run in turns according to the number of dice to plot according to Number Order, (5) every player has a chance to stop at the travel routes: (a) air route, the player is entitled to get an Air Pin, (b) fire route, the player must be swiftly put out the fire by putting out the provisions: code A goes out with Air Pin, APAR \& Call 113; code B goes out with Air Pin and Call 113 and code C goes out with Air \& Hydrant Pin $\&$ Call 113, (c) free parking routes: Players have the right to park their pieces at any number and (d) number the only route: Players must answer questions from the question card. (If the answer is correct, then the player is entitled to get 1 coin pin), (6) 1 pin Coin (Rp) can be exchanged for 2 Water Pins, (7) if the players succeed in putting out the fire exactly according to their classification then the player gets a Fire Pin, (8) if the Player is wrong in the process of putting out the fire then the player is given a penalty of losing 1 Pin of Water per 1 Pin of 
Fire per 1 pin of coins (Rp) and (9) the player with the most Pin Fire collections is the Winner.

\section{Dice}

In determining the magnitude of the route steps each player will take, a dice was used to determine it. Each player must roll the dice once. The number that appears on the surface of the dice determines the magnitude of the steps that each player wants to take. The size of the dice used in this game was $8 \mathrm{~cm}^{3}$ or $2 \mathrm{~cm}$ in length.

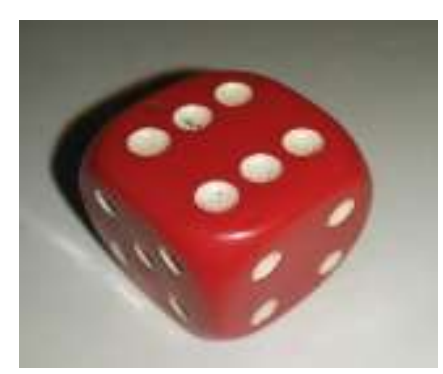

Fig.10. Dice

\section{Guide book}

The guide book contains matters relating to the application of a fire mitigation boardgame. The guidebook contains game rules, an explanation of GaMiKar equipment, types of routes in the game, educational material about fires, questions and answers to material, and some important information that must be known in efforts to prevent fires.

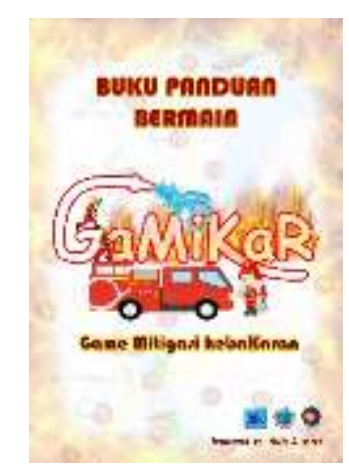

Fig. 11. Display of the cover of Gamikar's guidebook

\section{Game Box}

This game box is a place to store all game equipment. This box is made of used cardboard, then the appearance is changed by attaching stickers that have been designed in such a way that it can change the appearance of the former cardboard. The size of the cardboard is $31 \mathrm{~cm} \mathrm{x}$ $7.5 \mathrm{~cm} \times 20 \mathrm{~cm}$.

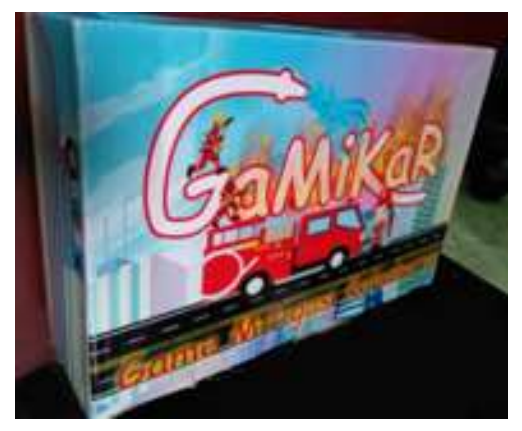


Fig. 12. Game box containing fire mitigation boardgame equipment

The board that has been named Gamikar after being developed, then the next step is to do a validation test. This validation test was conducted by 2 experts, namely science media learning material experts and fire mitigation material experts. The results of the validation test to the material experts can be seen in Tables 1 and 2 below. In the validation test, the matter of science learning media materials 3 aspects are assessed, namely the feasibility of the content, the feasibility of presentation, and the feasibility of language. Whereas in the fire mitigation validation test the aspect assessed was the feasibility of the graphic.

Table 1. Recapitulation of the assessment in Natural Sciences Learning Media Materials

\begin{tabular}{ccccc}
\hline Material Expert & Indicator & $\begin{array}{c}\text { Earnings } \\
\text { Score }\end{array}$ & $\begin{array}{c}\text { Maximum } \\
\text { Score }\end{array}$ & $\%$ \\
\hline Worthiness & Suitability & 10 & 12 & 91.6 \\
& Accuracy & 18 & 20 & \\
& Finesse & 8 & 8 & \\
Presentation & Encouraging curiosity & 8 & 8 & \multirow{2}{*}{. } \\
Feasibility & Presentation Techniques & 3 & 4 & \\
& Supporting Presentation & 23 & 24 & 100 \\
Language & Material Expertise & 4 & 4 & \\
Feasibility & Encourage Curiosity & 8 & 8 & \\
& Straightforward & 12 & 12 & \\
& Communicative & 4 & 4 & \\
& Dialogical and Interactive & 4 & 4 & \\
& Compliance with PPD & 8 & 8 & \\
\hline
\end{tabular}

In the content, validation test results were obtained $91.6 \%$ results. The appropriateness of the contents assessed includes 4 assessment indicators namely appropriateness, accuracy, finesse, and encouraging curiosity. Of the four indicators, the lowest validation results of experts are found in the indicators of material suitability. The suitability of the material is still considered to need to be improved because there are still several fire mitigation materials not yet included in the question card. So from the results of this validation test, the authors improve the contents of the question card that is to be used in this game.

In the validation test, the feasibility of the presentation obtained $95 \%$ results. The feasibility of the presentation consists of 4 assessment indicators namely presentation techniques, supporting presentation, material expertise, and encouraging curiosity. Of the four indicators, there are 2 indicators with low validation results, namely presentation techniques and presentation support. From the results of the validation of this expert, the writer evaluates the presentation techniques and supports the presentation. 
In the validation test results obtained by the language $100 \%$ results. These results indicate that in terms of language for the board game media has been declared feasible by meeting the four indicators, namely straightforward, communicative, interactive, and following the development of students. And from the three aspects assessed on the validation of science learning media experts an average of $95.53 \%$ was obtained and declared worthy of improvement.

Table 2. Recapitulation of Gamikar Media Expert assessment results

\begin{tabular}{ccccc}
\hline Media Expert & Indicator & Earnings & Maximum & $\%$ \\
\hline Feasibility of & Score & Score & 8 & \\
Graphic & BA Co Teaching Materials & 7 & 28 & 88.8 \\
& Design Content BA & 64 & 72 & \\
\hline
\end{tabular}

Whereas in the validation of fire mitigation media experts the aspect assessed was the feasibility of graphics. In this aspect, three indicators are assessed namely the size of teaching materials, cover design, and content design. Of the three indicators, the lowest validation result is in the design of the content, so that the design of the content needs to be evaluated for improvement so that it is feasible to be tested.

Product development (draft) Gamikar that has been developed based on a visual spec includes the use of colors, layouts, drawing styles, and typography writing. Writing and drawing using the dominant color scheme preferred by children such as red, yellow, green, blue. Display images on board games against the background of the Sintang city map become more conceptual with the daily life of elementary school students in Sintang. With writing style using the Comic Sans MS type, it becomes more attractive in the eyes of children in using Gamikar.

In Gamikar games, if a child can answer a lot of questions on the question card, then more rewards will be obtained in the form of a coin pin Rp. Likewise, the opposite applies. This game system is designed so that elementary students who will use Gamikar will continue to be motivated to learn the fire mitigation materials contained in the guidebook. The provision of rewards and punishments can have a major influence on student motivation. The right strategy will influence the learning process to increase continuously to achieve maximum results.

\section{Conclusion}

Based on the research development has been done by the author, it can be concluded that the draft "Gamikar" which declared invalid with the percentage of $95.53 \%$ by the validator learning media and $88.8 \%$ by validator fire mitigation. Thus "Gamikar" was declared feasible to be continued and tested on samples. Then the improvements made to the product are: the size of the fire patriot piece is reduced to make it balanced with the numbering on the Gamikar board game, adding rules to the boardgame Gamikar so students are more practical reading, add the question number to the question card so that students find the answer key in the guidebook easier, the size of the Gamikar box is reduced to make it more practical and easy for students to carry, and the size of the letters on the question cards is raised so that students more easily read the questions 
Acknowledgments. Thank the Lord Jesus Christ because of His blessing and all the other participant that already helped and supported our research. Thank Directorate of Research and Community Service, Directorate General of Research and Development, Ministry of Research, Technology, and Higher Education that has been funded our research under the 2019 budget year research contract with SK No.T / 140 / E3 / RA.00 / 2019. Thank the Fire Department of Sintang Region and Research and Development Unit (LPPM) of STKIP Persada Khatulistiwa Sintang.

\section{References}

[1] BNPB, "Jumlah Kejadian Bencana, Korban dan Dampaknya sampai bulan September 2016.," Jumlah Kejadian Bencana, Korban dan Dampaknya sampai bulan September 2016, 2016. [Online]. Available: http://dibi.bnpb.go.id. [Accessed: 21-Jul-2019].

[2] I. Y. Kurnia, "Kabut Asap di Kalimantan Barat," Kompas.Com, 2018. .

[3] Mirna, "tiga-korbandiduga-kebakaran-lahan-bocah-7-tahun-meninggal.," Tribunnews.com, 2018. [Online]. Available: http://pontianak.tribunnews.com/2018/08/13 /tiga-korbandidugakebakaran-lahan-bocah-7-tahun-meninggal. [Accessed: 25-Aug-2018].

[4] A. Junius, "ingat-kabut-asap-berpengaruh- besar-terhadap-perekonomian.," Kalbar.prokal.co, 2018. [Online]. Available: http://kalbar.prokal.co/read/news/2261-ingat-kabut-asapberpengaruhbesar-terhadap-perekonomian. [Accessed: 25-Aug-2018].

[5] S. Henry, Cerdas Dengan Game: Panduan Praktis Bagi Orangtua Dalam Mendampingi Anak Bermain Game. Jakarta: Gramedia Pustaka Utama., 2010.

[6] M. Griffiths, "Computer game playing and social skills: a pilot study.," Aloma Rev. Psicol., vol. 27, pp. 301-310, 2010.

[7] N. Setya, "Perancangan Board game untuk anak usia 8-12 tahun.," Sains dan Seni ITS, vol. 6, no. 1 , p. $63,2013$.

[8] Rismawati, Menstimulus Perkembangan dan Kecerdasaan Otak Anak dengan Permainan. Jakarta, 2002.

[9] M. Irlam, Bimbingan dan Konseling di SD. Yogyakarta: Pustaka Ar Ruzz, 2014.

[10] E. B. Hurlock, Psikologi Perkembangan: Suatu Pendekatan Sepanjang Rentang Kehidupan., 5th ed. Jakarta: Erlangga, 2012.

[11] S. Yusuf, Perkembangan Peserta Didik. Jakarta: Raja Grafindo Persada, 2013.

[12] N. Wedyawati, "Pembelajaran IPA Bervisi SETS Untuk Peningkatan Prestasi Belajar dan Peningkatan Sikap Tanggap Bencana Siswa Kelas IV SD Swasta dan Negeri.," J. Vox Edukasi, vol. 5, no. 2, pp. 43-50, 2014.

[13] N. Wedyawati, "Developing Integrated Natural Science Disaster Mitigation Model for Elementary School Sintang.," J. Educ. Sci. Technol., vol. 3, no. 2, pp. 164-172, 2017.

[14] N. Wedyawati, "Pengaruh Model Pembelajaran IPA Terintegrasi Mitigasi Bencana terhadap Hasil Belajar.," Edukasi J. Pendidikan., vol. 15, no. 2, pp. 261-273, 2017. 